\title{
THE HARMS OF STATE, FREE-MARKET COMMON SENSE AND COVID-19
}

\author{
Roy Coleman and Beka Mullin-McCandlish
}

\begin{abstract}
The markedly high levels of preventable death and injury from COVID-19 in the UK have been refracted by government appeals to "British common-sense" in response to the crisis. We critically explore this appeal as a generator of harm continuous with free-market common-sense (FMCS) that stretches back to the start of the 1980s and the Thatcherite assault on state protections, "enemies within" and expertise in the public realm, driving and legitimating a broad landscape of harm under neoliberal restructuring. This is the context for understanding government responses to COVID-19 and the Grenfell fire, both of which have resulted in avoidable death and injury and both of which illustrate the role of "common-sense" in the demonisation and blaming of the victims of state violence along with a deligitimation of expertise in public health. Following Gramsci's conceptualisation of common-sense and its role in cultivating a never-guaranteed consensus for the continuance of capitalist state power, we explore the emergence of Gramsci's "good sense" in the current juncture and its challenge to the harms of state that FMCS has generated.
\end{abstract}

Keywords: free-market; common-sense; Gramsci; good sense; state harm; COVID-19; Grenfell

For many, the UK response to the COVID-19 pandemic is evidence of a shambolic bumbling stupidity at the centre of Boris Johnson's government. This has a ring of truth but, for us, government responses to this disaster are indicative of more longterm and systematic shifts in state power that have generated victims of government policies through a "common-sense" narrative that both promotes and veils mass harms to populations of neoliberal capitalist societies. The Johnson administration's appeal to "British common-sense" to get through the pandemic has developed out of, and has continuities with, the Thatcherite common-sense free-market revolution that began in the late 1970s. From this time, politicians, CEOs and "leaders" in public services have increasingly represented themselves and their practices through "common-sense" as a lexical conduit to communicate, legitimate and discursively frame state and corporate policy. Even when such policy maims and kills people, the appeal to "common-sense" attempts to make such harms

Roy Coleman, Open University, UK

Beka Mullin-McCandlish, University of Liverpool, UK 
appear "unfortunate", probably inevitable and, therefore, an acceptable part of everyday life. A kind of common-sense has been centre stage in the UK from 1979, helping to shift the UK state to a law and order pole while at the same time draining public finances. We draw attention to continuities in the meaning and deployment of this Thatcherite common-sense as a leading and dominant rhetoric of government. Of course, it has never been entirely hegemonic but has been refracted through various Conservative administrations, New Labour and the recent coalition government. We term this free-market common-sense (FMCS). Its articulation today can be observed in relation to events such as Brexit, Grenfell and COVID-19. Like common-sense in general, FMCS has little to do with "truth" but is, as Antonio Gramsci remarked, a contradictory and often incoherent terrain of thinking and feeling. Nonetheless, its power becomes apparent when aligned to the material power of the state, allowing a state to lead and even appear "at one with the people". Common-sense appeals by the powerful express the power of states and corporations "in the vernacular, the familiar language of the street, the home, the pub, the workplace and the terraces [and] the tabloid press [which] . . ventriloquises the language and gnomic speech patterns of 'ordinary folk'" (Hall and O'Shea 2013: 9). As Stuart Hall has variously noted, since 1979 the shift to a free-market state and its governing of social relations has both reflected and reinforced a notion of "British common-sense", articulating ideas of "freedom", "fairness" and "the British way of life". These ideas have been marshalled for a FMCS that undermined collective sentiment toward welfare and social protection while extending punitive aspects of the UK state over a period of decades. This punitiveness has been both material and discursive. FMCS has always been an uneven, yet relatively coherent articulation of state practice. We discuss how FMCS has been articulated by recent governments to harness popular consent for neoliberal stripping back of social protections and the harms and injuries this has generated.

\section{Common-Sense and Free-Market Hegemony}

We argue that the harms inflicted by the state during the COVID-19 crisis, both material (lack of personal protective equipment, slow to action in regards to lockdown) and those bound in official rhetoric ("common-sense" thinking), have their roots in the propagation of free-market regressive politics instituted since 1979. Common-sense, or "everyday thinking”, provides meaning through a popular frame of reference without the need for complex thought, or the need for specialist knowledge. Above all it is pragmatic - "let us get this thing done", as Boris Johnson said in relation to Brexit — without need to think too much about what it being done, why, in whose interests and with what consequences. This rhetoric was a common theme throughout the Brexit campaign, which arguably won the 
Conservatives their landslide majority in 2019 (Perrigo 2019). Common-sense is a prevalent means of thinking and feeling that can cut across class, ethnicity and gender only in as much as it appears to relate to "common experience"- of what needs to be known about the immediate realities of everyday life. In and of itself, therefore, common-sense can do little or nothing but requires articulation and organisation by political leaders, corporate managers, powerful media outlets and states departments.

For Gramsci, common-sense is largely an ahistorical and inconsistent body of assumptions but also provides linkage between leaders and led. It lies at the root of a "conception of the world which is uncritically absorbed by the various social and cultural environments in which the moral individuality of the average man is developed" (Gramsci 1971: 419). When Gramsci set out to explain its role in specific political-economic formations, he described common-sense as containing a bizarre mix of "stone Age elements", "advanced science", "prejudices" from the past and "intuitions" about the future. Explaining how a ruling group establishes and maintains dominance over large populations, Gramsci argued that those in power govern by a mixture of force and consent, seeking to obtain the consent of the dominated, appealing to their "common-sense", folklore and intuitions. Leadership or hegemony presupposes that powerful groups take heed of, incorporate, mimic and orchestrate popular consciousness (or ways of feeling and thinking). A ruling group maintains domination because the dominated accept, they come to identify with the powerful and their ways of thinking as "just", "right" or "fair". Although Gramsci was at pains to point out that this process was never assured or guaranteed, he also saw common consciousness rooted in actions that, at times, directly contradict and challenge the ways of the powerful as materialised in the state.

Common-sense may be contradictory, based on superstition and folklore as well as science, yet it potentially knits "a people" together through common idioms, national ritual and maxims expressing ideas of "the hard-working family", "working for a living", "contributing to society" and being a "good citizen". Since 1979, a FMCS has developed within all manner of state practice-from its Thatcherite "enterprising individual" to the New Labour "light touch" regulation of business-helping routinise the marketisation of social relations through notions of "choice and "freedom"". It has also been twinned with feelings and discourses around "loss", not only pertaining to post-colonial melancholic dread (Gilroy 1987) but, relatedly, in terms of job losses in manufacturing, mining and the community structures of feelings associated with them (Clarke 2020). The success of FMCS has been to respond to "loss" in twinning conservative concerns with national pride (as a response to "losses") with generalised feelings of perceived threat to "our freedoms" from various outsider groups (immigrants) and "enemies-within" (welfare "scroungers", strikers). 
In this way, Thatcherism's national-popular restructuring of British capitalism through "common-sense neoliberalism" (Hall and O'Shea, 2013) has become "increasingly hegemonic [in] setting the agendas for debate" (2013: 21) around "fairness" in public welfare, social security, immigration, punishment and protection in the workplace. Successive governments have articulated "fairness" away from collective notions of welfare towards imaginaries around individual reward for "enterprise" and "effort". Welfare recipients became more easily identified as "scroungers" and those engaged in struggles for rights in the workplace as "nation wreckers": their experiences of a stingy benefits system or an unsafe workplace deemed irrelevant. This successfully tied British capital to a notion of "freedom": freedom to work, freedom to set up businesses and freedom to consume. It also established an agenda that encapsulated "freedom" from government regulation or aspects of control defined as "red-tape", enterprise-restricting health and safety rules, unnecessary planning permission and any kind of public service "do-gooding" that may hamper private initiative. By the end of the 1990s a new cultural landscape was ascendant: "The wealthy were adulated. All were now encouraged to scramble up the social ladder and be defined by how much they owned. Those who were poor or unemployed had no one to blame but themselves" (Jones 2011: 24). Over decades, this landscape muted the voices and experience of working-class people (Charlesworth 2004), and/or dismissed them as worthless objects of middleclass disgust, revulsion and exclusion (Lawless 2005; Tyler 2013). In this sense, the symbolism, rhetoric and imagery generated through FMCS has a targeted violence at its core-rubbishing, rejecting and "eliminating" so-called common enemies to an imagined free-market utopia and idealised Britishness.

Focusing on these cultural shifts helps an understanding of the landscape of intensified harm and violence, damaging the lives and life chances of groups in most need of dwindling state protections, public health services and public safety that have been whittled away as a result of free-market dogma. We argue that from the outset, FMCS implemented a form of collective self-harm-attacking welfare safety nets, democratic accountability, checks and balances protection and criminal justice and advancements in citizenship gained since 1945. Thatcher's famous allusions to "belt-tightening", "necessary hardships" and the end of the "something for nothing society" were elements of FMCS that by 1990, when Thatcher made the speech cited below, could be hailed as the "normal" model of socioeconomic governance through Europe:

The lessons we have all learned from experience ... is that regulation and central control of an economy do not lead to prosperity. It is ordinary enterprising people, given the freedom to follow their natural instincts in a system where markets are allowed to operate, who make themselves and their country prosperous ... and 
[as] painful as their short-term consequences may be [because] reform that is effective is usually painful [and] people will always preserve and endure hardship if they understand that it will lead to a better life (Thatcher 1990, emphasis added).

Whilst trickle-down economics was meant to provide "rewards for all", what actually persevered was a normalisation, extension and seemingly unending defence of hardship, pain and suffering as the grist of day-in day-out politics for those not blessed with entrepreneurial acumen. In this market vision, public welfare and associated expertise promoted an idle population disinclined to hard work and enterprise. Governing strategies promoting hardship focused on dismantling a range of expertise in public welfare and had real material consequences for deregulating landscapes of harm: repealing workers' rights, attacks on safety, health, welfare and education in which FMCS has redrawn British social life pre and post COVID-19. The continuities over decades are found in a celebration of enterprise whilst demonising the social state and its expertise (doctors, teachers, social workers and all manner of public service workers). Recently, this aspect of FMCS was dramatically appealed to by free-market purists and anti-European little-Englanders who, during and after the Brexit debate, urged the voting public to reject "experts" in favour of "freedom" in order to unleash the "natural talents of the British people" hampered only by the overburdening state regulatory framework of the European Union (Luyendjik 2019).

This overview contextualises the discussion of the current UK governmental responses to COVID-19 and events such as Grenfell. However, it must also be noted that these events exemplify FMCS as a powerful rhetorical device of governing that, at the same time, displays tensions, fragilities and contradictions ensconced in FMCS as a hegemonic discourse. Indeed, although the Grenfell Tower fire was touted as both "unprecedented and "unforeseen", despite being an accumulation of central and local government failings, it laid bare the importance of understanding the political-economic-cultural determinants of health (McKee 2017). While we wish to interrogate how FMCS has disguised and promoted the harms of state (non)intervention under free-market conditions, we also ask: how effective and successful is FMCS in projecting state-market power in the current juncture?

While FMCS is very much in evidence decades on from the early 1980s, it arguably has a reduced impact and appeal. The harm FMCS has sought to normalise has come up against contrary experience and practice on the ground in the struggle with COVID-19. We shall return to this in more detail. As current figures concerning death rates show, it is still these minoritised groups who bear the brunt of the effects of COVID-19 (gov.uk, 2020) and those who work in public services have been differentially put at risk. At the same time, FMCS is being challenged 
by community activists, critical academics and even elements in mainstream media. The latter have played a role in highlighting the shortcomings of the current government during the crisis and their initial attempt to "brush off" the threat of the virus in favour of keeping markets open (The Sunday Times, 2020). There is evidence that while Gramsci's indication that common-sense will always have some role in state leadership and domination, it is also unstable and open to challenge from elements within itself as practice and action decouple from governing "sense" and rhetoric. Gramsci called this good sense. As indicated later, when ascendant, good sense can provide popular legitimacy for a movement to transform the state and rethink its relationship to "public interests".

\section{Appealing to "Common-Sense" in the Wake of Grenfell}

During the 2019 general election, Conservative Leader of the House Jacob ReesMogg was asked about the Grenfell Inquiry report. He said

[t]he more one reads over the weekend about the report and about the chances of people surviving, if you just ignore what you're told and leave you are so much safer. And I think if either of us were in a fire, whatever the fire brigade said, we would leave the building. It just seems the common-sense thing to do (BBC News 2019).

This narrative of "common-sense" implies that resisting the expert guidance of the fire service would have been the "sensible" thing to do. Rees-Mogg was merely advocating a Thatcherite continuity in its common-sense onslaught on aspects of social democracy since 1945 and the expertise and knowledge associated with it. He was merely articulating minimal statism in which public sector experts, in Thatcher's time and now, are decried as "against the essence, the Genius, of the British People" (Hall 1983: 34). As enemies of "common-sense", experts are by implication, enemies of the people - dangerous to "our freedom" or part of a category of "enemies within", as Thatcher put it. Here, common-sense underpins a "no such thing as society" vision in which the self-responsibilised individual and the "hardworking family" reign. Rees-Mogg also evoked another element of FMCS. His assumption was that the Grenfell victims were outside of "British" common sentiment, as he was articulating it: they were largely nonwhite, of immigrant status, perhaps they had been "too deferent" to experts and, therefore, "lesser breeds" (Gilroy 1987). Of course, the narrative of FMCS is one that is intrinsically linked the concept of "the nation". Following Anderson's (1983) theory of "imagined communities", "British common-sense" is not tangible or concrete; rather it is a sense or feeling of shared values, it provides a 
fictional connection to others and underpinned the violence of the "hostile environment" for immigrants featured in Theresa May's administration. It is exclusionary by its very nature: it paradoxically assumes that the ability to utilise "common-sense" is both a natural characteristic and one that is embedded in and created by "British culture".

When Rees-Mogg claimed that the victims of Grenfell should have exercised common-sense and, therefore, avoided death and injury, he was expounding an established free-market maxim that states are not the natural protectors of properly responsibilised individuals. Since Thatcherism, the individual has taken on a particular meaning: a resilient individual who can stand "on their own two feet": someone who can take the advice of one of Thatcher's key lieutenants and "get on yer bike", find employment and renounce welfare from the state (Wild 2007). This is an individual who is self-responsibilised and wishes to break free from a "dependency" on state assistance and despises those who cannot. Rees-Mogg conjures up this same individual — one who thinks not of the decades-long roll-back of the social state (more recently in terms of austerity measures) and severs it from the path that led to the Grenfell fire. These sentiments plug into a view that it is only the poor, foot-draggers and politically voiceless who mistakenly remain wedded to a fantasy of listening to experts who claim knowledge on public health and safety. However, over the last 20 years, these same poor people are routinely subject to a new kind of "expert" to arise in old and new media. This is the "makeover" expert who can preen and judge "a lifestyle", offering guidance to those without "dress-sense", in possession of "untidy homes" and "incorrect" diets. In this world, expertise as window-dressing has morphed with FMCS with its emphasis on individual consumerist disciplinary tutoring. It is now just common-sense to "make-over" and air brush the signs of dilapidation and poverty in an era of welfare roll-back. The highly toxic make-over cladding on Grenfell Tower itself and other tower blocks in the UK is testament to that. It is part of the same commonsense that puts a premium on market consumerist solutions to social and political problems, necessitating a cleaned up, air-brushed presentation of those bodies and eyesores that fail to acquiesce, aspire and compete in market terms.

Part of our concern is to trace FMCS into the heart of governing in the form of official inquiries or other quasi-judicial forums. How might FMCS enter these realms and appear as "evidence" and accepted/normalised assumptions informing the inquiry findings? The remit of the Grenfell inquiry, laid out within the terms of reference, includes - but is not limited to - the immediate cause of the fire, the adherence (or lack of) to building regulations during the construction and refurbishment phases (with particular interest in the nature of the cladding), the actions of the local authority and the response of central government (Grenfell Tower Inquiry 2017). The Grenfell Inquiry has not framed its investigations in terms of 
scrutinising state-corporate harms and derogation of health and safety in the context of Thatcherite inspired privatisation, state deregulation and the masking of accountability in public services. Indeed, the Grenfell Inquiry exemplifies the pervasive nature of the common-sense we have been referring to, with all its ramifications for corporate obfuscation. Like Rees-Mogg, corporate representatives brought before the Inquiry can draw on a wider cultural space to deny culpability and deflect attention from their own political and corporate actions, weaving their testimony with taken-for-granted assumptions concerning long-derided ethnic groups and the poor. For example, in July 2020 the Grenfell Tower Inquiry heard evidence from Rydon Construction LTD. Simon Lawrence, Rydon's contract manager during the refurbishment period which saw the flammable cladding be installed, explained in his testimony that the Kensington and Chelsea Tenant Management Organisation (TMO) had explained to him that "there were several vocal residents and one of which could be extremely vocal and was quite well known by the TMO" (Apps 2020). He continued "I felt there were several very vocal, dare I say it aggressive, residents that in my opinion regardless of what work was being carried out would still have found a reason to complain". Lawrence's rhetoric evokes the image of an "ungrateful" working class, whose calls for safe housing has seen them become labelled "aggressive rebels", even though these descriptions have been replayed posthumously in some cases. Simon Lawrence's words echoed a familiar rhetoric that had been present in discussions of the residents of Grenfell Tower at local authority level. In 2018, emails revealed that a worker at the Royal Borough of Kensington and Chelsea (RBKC) had been describing the residents as having "language problems, lack of education and understanding how anything works", while also comparing them to "gangs" (Booth 2018). Those residents who did not have secure immigration status had also been victims of the "hostile environment" created by Theresa May's government, with some too afraid to come forward to seek support in the aftermath of the fire due to the consequences they may face during interactions with the state, such as being detained or deported (Bradley 2019): "People would face three rounds of applications over five years and the state reserved its right to refuse and deport them on the basis of their perceived "character, criminality or associations" (Home Office, cited in Bradley 2019).

While class and ethnicity in the UK are a predictor of overall health and life expectancy (Wohland et al. 2015), as well as poverty, the pervasive narrative of an "undeserving poor" still permeates media and political dialogue regarding those who utilise government welfare programmes. It can also be argued that racism itself, particularly when enacted by the state, can have negative health effects. The victims of the recent Windrush scandal are an example of this: they were stripped of their homes and livelihoods and several have since died during the process of 
deportation, with family members citing stress and lack of income as reasons for their deaths (Bradley 2019). The "hostile environment" policy reflected and reinforced existing repertoires of FMCS, racialising attacks on welfare recipients, immigrants and the poor. It cannot be overlooked that poverty and racism go hand in hand, and that racist policies, historic and current, impose state-sanctioned class barriers on ethnic minorities in the UK.

\section{Free-Market Common-Sense: Its Appeal and Instability in Responses to COVID-19 in the UK}

At the beginning of the European outbreak of COVID-19, it was touted as "the great equaliser" (Mein 2020). The message that nobody was immune, despite wealth, race or fame was optimised by high-profile cases such as Idris Elba, Tom Hanks, Prince Charles and of course Boris Johnson himself, who was hospitalised during the midst of the first UK lockdown. The mainstream media as well as political discourse shaped this notion of health equality, with the exception of the acknowledgement of age as a predictor of mortality. However, historically pandemics have the ability to amplify pre-existing health inequalities (Mein 2020), and with the emerging findings from the Office of National Statistics (ONS), it has become clear that those at highest risk of death from COVID-19 are those dubbed as "low-skilled" workers, often on the frontline of the pandemic, and individuals from Black, Asian and minority ethnic (BAME) backgrounds (White and Nafilyan 2020).

Free-market common-sense has been central to UK government articulations of COVID-19 and policy responses to it. At the same time, FMCS has shown signs of a ventriloquism that lacks "authenticity". For Gramsci, it is in moments of uncertainty or crisis when schisms between thought and action are productive ground for shifts in popular and political understanding: common-sense becomes less "spontaneous" and cohesive in its messaging and ability to cement leadership. Previously successful common-sense notions that might have "worked" in "normal times" suddenly appear old and ill-fitting of the situation and experience on the ground. Gramsci saw this as a shift in collective consciousness that may arise in "flashes" when a subordinate group realises it has "adopted a conception which is not its own but borrowed from another group" and fails to adequately "explain" a subordinate group's experience and its actions (1971: 326). The recent experience of COVID19 in the UK population including transport workers, care workers and educators is an example of this process and, borrowing Gramsci's phrasing, points to a situation where "the general interests of the subordinate groups and the life of the state" can no longer be "conceived as a continuous process ... superseding unstable equilibria" (1971: 182). The unifying power of FMCS may be showing signs of waning, 
perhaps indicating the project of marketised social relations is in retreat. As we have seen, Gramsci argued that when "common-sense" is "successfully" wedded to a strategy of economic domination, it allows the latter to pass as "spontaneous" and "instinctual": unspoken, "obvious" and largely self-evident (Crehan 2011).

However, as the COVID-19 crisis endures, schisms are noticeable in a FMCS governing strategy. From the vantage point of FMCS, a previously unimaginable insistence on "following the expert science" was introduced in the UK coronavirus briefing, as if science is a single, homogenous consensus that can either be followed or not. Of course, this has been a tale of science subservient to governing strategy and FMCS. Science has become increasingly blurred with politicking, market pressures to financialise vaccines and corporate/governmental spin. In this scenario, we are not privileging science over common-sense. Both have reinforced each other in generating further harms during the pandemic. Hand-picked scientists in and around UK government (SAGE) have been subservient to free-market rhetoric, for example, on mask wearing both in the UK and in the US, and in their role on the timing of lockdown and its exit. This is evidence of the subservience of science to sowing spin and confusion within FMCS. A vast swathe of scientific opinion outside of government has sounded more like Gramsci's good sense than government "science" that clearly has spoken on behalf of a free-market continuation of the "new normal" (Ashton 2020). Outside of government science questioning the dangers and harms from "quick-fix" vaccines that serve big pharma profit-seeking and governing legitimacy (Gu 2020). An emergent good sense is evident in the science articulated and practiced outside of, and contradictory to, UK government (as witnessed in the different approach by the Scottish Assembly).

The Johnson government's daily briefings between 16 March and 18 June 2020, subsided to briefings "as and when necessary", which arguably signalled the "unlocking" of the UK's preventative measures. Their format would often begin with a speech headed by a member of the cabinet, sometimes Boris Johnson himself, and this was supported by medical advisors, most notably Chief Medical Officer for England Chris Whitty and Chief Scientific Advisor to the Government Patrick Vallance. A common theme throughout these briefings, particularly those that announced a change in lockdown measures, was that every choice was being made due to "the science", painting an image of apolitical decision-making that was out of the hands (and responsibility) of the Johnson government.

The government's appeal to science has been hollow window-dressing and marries with FMCS's disdain for all forms of expertise. Instead, government messaging has been based on maxims. For example, the Johnson administration has moved from its earlier "stay Home" to the later "stay Alert" as part of the UK's easing of lockdown. Members of parliament, including the prime minister, urged the public to use "good, solid, British common -sense" to interpret the "stay Alert" 
rules as public and private space is reopened. This coheres with Johnson's own COVID-19 hospitalisation and its tabloid reporting. The PM spoke of the illness as like "fighting off a mugger", colleagues spoke of his "fighting spirit" and, before he became ill, Johnson spoke of Britain going it alone against the pandemic and "remaining open for business". Of the disease, he said Britain would "take it on the chin" (Shariatmadari 2020). The government's herd immunity strategy (the weak die, the strong gain resilience to infection) has not been spoken aloud but it is clear this is supported by reference to FMCS in this crisis. The comments around Johnson's illness point to the efficacy of herd immunity in Johnson's administration and demonstrate continuity in its common-sense strategy for promoting "resilient individuals" alongside maintaining market trading.

Such government pronouncements are reminders to a populace that it needs to individually "stay Alert" and think and act outside of collective solutions to social problems. Welfare, health and public safety are matters of individual choice and responsibility. These are the hallmarks of Johnson, Trump and Bolsonaro state leadership. These market-states are the sites of the highest death counts (at the time of writing) and demonstrate the limits and contradictions of common sensical responses to the pandemic, including the sometimes tragi-comic elements associated with Trump's suggestion that ingesting disinfectant will fight-off coronavirus. Whilst common-sense can be a tactic of government power that can become dominant in the public imagination, it is - as Gramsci noted - inherently unstable, "not something rigid and immobile, but is continually transforming itself" (1971: 326). There are limits to how much "common-sense" appeal can aid those in power. In this sense, the "spontaneity" of Johnsonism is becoming less apparent in the face of a transformational common-sense rooted in actions on the ground in response to COVID-19 that are beginning to articulate non-marketised notions of fairness and justice.

The contradictions and tensions in common-sense government legitimacy are clear in Johnson's call upon the public to use British common-sense in the "battle" against the pandemic: it is paradoxically both muddy and crystal clear. It is "clear" in its continuity: relaying the long-standing messages to the public not to look to the state for guidance and protection and "unclear" in its sham deployment of "the science". The actions the individual should take are ambiguous; does one follow expert advice: "the science"? The pandemic has reintroduced the importance of health experts, who- like other public sector representatives such as fire fightersfree marketeers might want to ignore but cannot do so entirely. But these experts are largely outside of government and not the hand-picked ones witnessed alongside political leaders. Normally, FMCS has constructed expertise as a concoction of extreme Left-leaning, do-gooding interferers, representative of public sector bloating. On the other hand, during the pandemic there was the "clap for carers" 
alongside side the slogan of "save the NHS". These governing rhetorics reflected and reinforced FMCS and attempted orchestration of public support for government strategy. That strategy had, over the long-term, underfunded and demonised National Health Service (NHS) workers and, more recently, masked this underresourcing by the national cancellation of surgeries and other treatments so the NHS could "deal with the pandemic". In this sense weekly clapping for carers, would for many have meant applause for non-existent care and postponed treatment resulting in unnecessary injury, harm (and death) as people were told to stay away from surgeries for non-COVID-19 symptoms.

Are the limits to FMCS now apparent? The embodiment of FMCS in the persona of Boris Johnson and his "charismatic" non-politician/comical appeal now looks curiously out of place. His joviality in trying to reopen business remains wedded to the Thatcherite common-sense expressive of the "liberty-loving Great British (increasingly English) people". What is becoming clear, however, is that any blame for unfavourable outcomes of flouting lockdown rules should fall with individuals if they should fail to act responsibly. One could argue that "flouting the rules" to an unacceptable degree could now simply be defined as not exercising such common-sense "correctly". This level of government gaslighting of its public was never clearer than during the Dominic Cummings scandal in May 2020. The special political advisor broke the then guidelines to "stay at home", advice given by the scientists, and yet the message from the prime minister on this rule breaking was one of empathy and admiration. Cummings, according to the government, had exercised his common-sense "responsibly". He was following "the instincts of every father and parent", according to Johnson. This appeal to FMCS displayed the latter's limits, failing to "ring-true" and appeal to swathes of the British public (Hall 2020). There are those in the administration who would prefer the science and expertise out of the equation and governing strategy. Presumably, in that scenario, the Cummings drama and his rule infringements would not be up for debate. Alas, pandemics call for expertise (even if it is stagemanaged, bogus and ignored) and this has created tensions for what is increasingly looking like an "old", outmoded common-sense.

Internal contradictions and misfirings in FMCS, such as the above, can be placed alongside emergent community campaigns emanating from Grenfell and COVID19 that are decoupling "fairness" and "justice" from market and/or individualised "solutions". They are challenging the mantra of "we are all in this together" (but only as individuals) in which self-interested consumerist "solutions" come first. Because of changed action on the ground as a result of autonomous and independent responses to events, new and critical elements of common-sense are questioning government policy, with a renewed sense of respect and compassion for health workers, immigrants, workers and other experts concerned with public health, 
public transportation and welfare provision. On the back of "clapping for carers" came the Johnson administration's usual business of verbal attacks on health workers and teachers as lacking resilience in aiding the end to lockdown, helped by tabloid hate speech. However, widespread public support for the public sector has persevered (Clarke 2020) and increased with the pandemic. This means that FMCS is becoming, using Gramsci's terms, merely "verbal", meaning that it no longer adequately explains or fits with action undertaken within wider civil society. This renders FMCS "fossilised", causing breaks, shifts and change in the collective conscience (Gramsci 1971: 326-333) as the violence and harm of state complicity in responding to the pandemic become more visible, alarming and in need of combative interpretation for growing swathes of the population.

\section{Dislodging FMCS: A Time for Gramsci's "Good Sense"?}

Gramsci reminds us that laissez-faire economics is an articulation of "freedom", not freedom sui generis. He indicates that free markets are ideological and material formations flowing from government regulation and strategising, and, finally, that "common-sense" is integral to this regulation under the auspices of a ruling bloc:

[i]t must be made clear that laissez-faire too is a form of state regulation, introduced and maintained by legislative and coercive means. It is a deliberate policy conscious of its own ends, and not the spontaneous, automatic expression of economic facts (1971: 158).

This admits the importance of ascribing cultural representation and cultural meaning to economic facts. Successfully articulated and moulded, common-sense can provide a ruling bloc with regulatory legitimation and support for state violence against "internal-enemies" in linguistic and physical terms. Laissez-faire conservatism and its articulation in FMCS may have reached its heyday with Thatcherism and gained renewed impetus under the refractions of Prime Minister Blair. In the UK, we have hinted at how FMCS has-"as far as it has been victorious"changed the "states ruling personnel... [and] the economic programme of the state itself" (Gramsci 1971: 158). Over the last four decades, this programme has proved harmful and divisive and FMCS has veiled and legitimised what others have consistently documented as clear increases in "safety crimes" under the reregulation of markets, privatisation and withdrawal of state protections (Tombs and Whyte 2007; Tombs 2016).

However, common-sense conceptions of the world each have their moment of power but eventually become "superficially explicit or verbal" in which conceptions "inherited from the past" can no longer be "uncritically absorbed" by masses 
of people (Gramsci 1971: 333). The COVID-19 crisis in the UK demonstrates the limits of FMCS as a rhetorical device that continues to be deployed but in a world in which state intervention itself appears to contradict it along with autonomous communal action evident at Grenfell, Black Lives Matter and in response to COVID-19. As the economy came to a screeching halt in mid-March, the managed return of the decades-demonised social state became evident. FMCS remains the means to manage this "return", as witnessed in current government and media discourse that is framing furloughing, the recourse to Universal Credit and other aspects of this limited welfare for the people. Almost two million people were forced to sign on to Universal Credit, a "tenfold" increase in claims (BBC News 2020). Coronavirus has rendered much of the public temporarily dependent on state welfare, whether through Universal Credit or the furlough scheme, and this has made visible the underpinning philosophy of the Conservative government's welfare system; the assumption of a moral underclass normally despised (Daguerre and Etherington 2014). The moral underclass discourse situates poverty as an individual failure rather than a structural problem, caused by "chaotic" lifestyle choices such as family breakdown, educational failure and addiction. While the unemployment rate during the current pandemic is evidently an issue of access to work, the discourse from the government has been consistent in its message of help being available for only the absolute minimum necessary timeframe. This was evident in Chancellor of the Exchequer Rishi Sunak's move to "wean" businesses and workers off the furloughing scheme due to fears that the public would become "addicted" to the financial aid (Smith 2020). The implication, or the "common-sense" assumption, is that the larger the welfare state, the more likely individuals will become "lazy" and "work shy". This is the "common-sense" thinking that led to a successful smearing of Corbyn's socialism in both the 2017 and 2019 general elections. Gaps in the government's self-employment package also highlight an assumption that those reliant on state benefits will "cheat the system", reflected in the lack of support for the newly self-employed, PAYE freelancers and those who earn less than 50 percent of their income from selfemployment (Rana 2020) who are unable to "reliably prove" their entitlement to income. Again, the narrative of FMCS is utilised here, as Rishi Sunak has repeatedly claimed "of course, we cannot protect every business and every household". It is, in short, both expected and understandable that some will be left behind. This echoes Johnson's claim earlier in the pandemic that inevitably "many more families will lose loved ones". It has not gone unnoticed by some mainstream media, however, that despite government claiming to do everything within their power to save lives, the largest increase in death rates in Europe belongs to the UK (Campbell and Morgan 2020) and despite the slogan of putting our "arms around everyone" as the crisis unfolded, it is notable that transport workers, care home 
and hospital staff all continued to work in perilous conditions and disproportionately suffered, and are suffering, the differential violence of the pandemic as lived through the longstanding inequalities around "race", class and citizenship.

Those from ethnic minority backgrounds face a double disadvantage as structural racism at state level can push them into poverty. The Black Lives Matter (BLM) protests in the wake of the death of George Floyd in May 2020 were enacted globally, calling for an end to, or at the very least an acknowledgement of, structural racism that has become so deeply embedded in everyday statesanctioned practises such as policing, it has become an extension of the commonsense narrative in and of itself. It has been stated that BLM may be the largest movement in U.S. history (Buchanan et al. 2020), and protests since Floyd's killing have been held on almost every continent (Kirby 2020). While Grenfell, the response to COVID-19 and the killing of Floyd may appear to be unrelated events, we argue that they are very much connected in two key ways. First, they make visible the very real harms enacted on ethnic minorities and the working class who routinely service capitalism in crisis conditions and often die for it. Second, and more optimistically, they also provoke a reaction from the general public, a reaction that challenges the insidious nature of the racist and classist discourses that surround these events and obfuscate them as routine state violence, both legitimated and mystified in FMCS.

FMCS has for too long fostered an impunity for the powerful and denied accountability for their dangerous actions in relation to a range of government and corporate decisions covering planning, workplace injury and ill health, public health and urban regeneration (Tombs and Whyte 2003). It has aided governments who ignored calls from the (silenced) residents of Grenfell years prior to the fire, and a government that still has not removed the dangerous cladding from 2,000 buildings in the UK three years after the fire. In this sense, those across civil society who have supported undermining trades unions, part-privatising the NHS (or transport) and the curtailing of public services, have often done so through the repertoire of FMCS and its valorisation of "individual initiative", business glamification and no "bottomless purse" for public funding.

FMCS has been harmful on many related levels, including the cultural licensing of the harms of the powerful, but also in the promotion and exploitation of divisions in Britain between welfare/enterprise, poor/wealthy, black/white and public sector/private sector. In a sense, FMCS coheres with so-called sadopopulism making inequality, harm in the workplace and environmental disasters "the new normality" that "we have to get use-to". In this scenario, we are encouraged to discard notions that states can intervene and make a difference. FMCS is a kind of self-inflicted injury that is at the same time celebrated in backward-looking nationalistic terms. The harms generated in the name of FMCS may be more 
obvious with events like Grenfell and COVID-19 but they are also reflected in a casualised political discourse that rejects the austerity-inflamed demolition of public services, the prowling dexterity of capital reregulated through privatisation, bullying management and self-aggrandised sloganeering in which everything corporate is "world-class". The Johnson incarnation of FMCS has added to the litany of harms to democracy itself-attempting suspension of parliament, lying repeatedly on matters of health, public security and promises of government commitments (Campbell 2020).

What social forces might be in position to article the embers of a new commonsense that gravitates around Gramsci's good sense? Such a new sensibility must have autonomy and critical debating at its core and will spring from, and articulate, action on the ground. It will need to do what FMCS appeared to do successfully from Thatcher's time and articulate "loss". FMCS from its Thatcherite incarnations to the present has been predicted on a sense of and reprojection of "loss" (Clarke 2020). Both traditional and new media have been central to the crafting of common-sense appeals and sentiments of "loss" associated with displacement and feelings of desertion among increasingly larger numbers of white working-class groups and communities. With Brexit we have seen the building of a hyper-regressive Right in the form of a "Boris Bloc" (Clarke 2020) that has deliberately continued to vocalise market interests through sloganeering around the pandemic, Grenfell and Brexit.

Articulating "loss" with "good sense" would decouple the latter from free marketisation, deregulation, punitive statism and the sadopopulism of the Right. As common-sense contains critical and utopian elements needed to build something "just" and "fair", "good sense" represents the "the healthy nucleus ... which deserves to be made more unitary and coherent" (Gramsci, 1971: 327, emphasis added). Gramsci could have been referring to sentiments now being voiced around the socially murderous free market, culpable in the Grenfell fire and the pandemic. The preventable and avoidable deaths and injuries that define these events are also a result of common-sense-based attacks on public funding and public sector workers, who have gone from Thatcher's "moaning Minnis" and unnecessary "dogooders" to "heroes" in recent months. This contradictory landscape and the battle over the presentation and meaning of our most precious public services and servants demonstrates an increasingly unhinged government's attempt to remake a no-longer unquestionable FMCS alongside Grenfell and COVID-19. In Gramsci's terms, we are at a moment when FMCS no longer provides "clear theoretical consciousness" to "practical activity" (Gramsci 1971: 117). This is a moment to rethink and refeel "loss"; rearticulate it with the frustrations, inequities and abandonments that continue to disproportionality impact under FMCS and so brutally exposed with COVID-19, Grenfell and, as yet to be realised, Brexit. 


\section{Acknowledgements}

Extended thanks are due to Steve Tombs, Stjepan Mestrovic and Joe Sim for their helpful critical dialogue during the writing of this paper.

\section{References}

Anderson, B. (1983) Imagined Communities. London: Verso.

Apps, P. (2020) "Rydon manager brands Grenfell residents who complained about fire safety 'aggressive'", Inside Housing, 22 July. Available online at: www.insidehousing.co.uk/news/news/rydonmanager-brands-grenfell-residents-who-complained-about-fire-safety-aggressive-67256 (accessed 10 August 2020).

Ashton, J. (2020) "The cost of Boris Johnson's COVID-19 'business as usual", Byline Times, July 8. Available online at: https://bylinetimes.com/2020/07/08/the-cost-of-boris-johnsons-covid19-business-as-usual/ (accessed 15 August 2020).

BBC News (2019) “Grenfell Tower: Jacob Rees-Mogg criticised for 'insulting' comments”, 5 November. Available online at: www.bbc.co.uk/news/uk-england-london-50302573 (accessed 10 August 2020).

BBC News (2020) “Coronavirus: Nearly two million claim universal credit”, 4 May. Available online at: www.bbc.co.uk/news/uk-politics-52536210, (accessed 10 August 2020).

Booth, R. (2018) "Grenfell emails reveal turmoil at council in aftermath of fire", The Guardian, 8 June. Available online at: www.theguardian.com/uk-news/2018/jun/08/grenfell-emails-reveal-turmoilat-council-in-aftermath-of-fire (accessed 10 August 2020).

Bradley, G. (2019) "From Grenfell to Windrush, state racism kills - sometimes quickly, sometimes slowly", Open Democracy, 13 June. Available online at: www.opendemocracy.net/en/opende mocracyuk/from-grenfell-to-windrush-state-racism-kills-sometimes-quickly-sometimes-slowly/ (accessed 10 August 2020).

Buchanan, L., Bui, Q., and Patel, J.K. (2020) "Black Lives Matter May Be the Largest Movement in US History", The New York Times, 3 July. Available online at: www.nytimes.com/interactive/ 2020/07/03/us/george-floyd-protests-crowd-size.html (accessed 10 August 2020).

Calvert, J., Arbuthnott, G., and Leake, J. (2020) “Coronavirus: 38 days when Britain sleepwalked into a disaster", The Sunday Times, 19 April. Available online at: www.thetimes.co.uk/article/corona virus-38-days-when-britain-sleepwalked-into-disaster-hq3b9tlgh (accessed 10 August 2020).

Campbell, A. (2020) "MPs need to stop letting Boris Johnson gaslight the public and stand up for honesty", The Independent, 12 July.

Campbell, A. and Morgan, E. (2020) "Comparisons of all-cause mortality between European countries and regions: January to June 2020", Office for National Statistics, 30 July. Available online at: www.ons.gov.uk/peoplepopulationandcommunity/birthsdeathsandmarriages/deaths/articles/com parisonsofallcausemortalitybetweeneuropeancountriesandregions/januarytojune2020 (accessed 10 August 2020).

Charlesworth, S. J. (2004) "Reflections on working-class space, being, and experience", Space and Culture, 7(3): 327-342.

Clarke, J. (2020) "Building the 'Boris' bloc: angry politics in turbulent times", Soundings: A Journal of Politics and Culture, 74: 118-135.

Crehan, K. (2011) “Gramsci's concept of common sense: a useful concept for anthropologists?", Journal of Modern Italian Studies, 16(2): 273-287. 
Daguerre, A. and Etherington, D. (2014) "Welfare Reform in the UK under the Conservative-led Coalition government: ruptures and continuities". Available online at: www.mostewartresearch. co.uk/wp-content/uploads/2018/01/Welfare_Reform_in_the_UK_PubReady.pdf, (accessed 10 August 2020).

Gilroy, P. (1987) There Ain't no Black in the Union Jack, The Cultural Politics of Nation. London: Routledge.

Gov.uk (2020) "COVID-19: Understanding the impact on BAME communities", Gov.uk, 16 June. Available online at: www.gov.uk/government/publications/covid-19-understanding-the-impacton-bame-communities (accessed 10 August 2020).

Grenfell Tower Inquiry (2017) Grenfell Tower Inquiry. Available online at: www.grenfelltowerin quiry.org.uk/key-documents (accessed 10 August 2020).

Gramsci, A. (1971) Selections from the Prison Notebooks. London: Laurence and Wishart.

$\mathrm{Gu}$, E. (2020) "This is the hard to swallow truth about a future corona virus vaccine (and I am a doctor)", The Independent, 13 June.

Hall, P. (2020) "The dangerous legacy of the Cummings affair", New Statesman, 8 August.

Hall, S. (1983) "The great moving right show" in Hall, S., Jacques, M. ed. The Politics of Thatcherism. London: Laurence and Wishart.

Hall, S. and O'Shea, A. (2013) “Common-sense neoliberalism”, Soundings, 55(1): 9-25.

Jones, O. (2011) Chavs: The Demonization of the Working Class. London: Verso.

Kirby, J. (2020) “'Black Lives Matter' has become a global rallying cry against racism and police brutality", Vox, 12 June. Available online at: www.vox.com/2020/6/12/21285244/black-lives-matterglobal-protests-george-floyd-uk-belgium (accessed 10 August 2020).

Lawless, S. (2005) "Disgusted subjects: the making of middle-class identities", The Sociological Review, 53(3): 429-446.

Luyendjik, J. (2019) “Europe isn’t the enemy - demonising us is undermining Britain”, The Guardian, 29 September.

McKee, M. (2017) "Grenfell Tower fire: why we cannot ignore the political determinants of health", British Medical Journal, 357: 1-2.

Mein, S. A. (2020) "COVID-19 and health disparities: the reality of "the great equalizer", Journal of General Internal Medicine, 35(8): 2439-2440.

Perrigo, B. (2019) “'Get Brexit Done': The Three Words That Helped Boris Johnson Win Britain's 2019 Election”, Time, 13 December. Available online at: https://time.com/5749478/get-brexitdone-slogan-uk-election/ (accessed 10 August 2020).

Rana, J. (2020) “"Excluded': 3 million self-employed locked out of support have their hopes dashed as Rishi Sunak fails to help them in his mini-Budget", This is Money, 9 July. Available online at: www.thisismoney.co.uk/money/smallbusiness/article-8502689/Forgotten-3million-self-employedfail-help-mini-Budget.html (accessed 10 August 2020).

Shariatmadari, D. (2020), “'Invisible mugger': how Boris Johnson's language hints at his thinking”, The Guardian, 27 April. Available online at: www.theguardian.com/politics/2020/apr/27/muggers-andinvisible-enemies-how-boris-johnsons-metaphors-reveals-his-thinking (accessed 10 August 2020).

Smith, D. (2020) "The dangers of becoming addicted to Rishi Sunak's job furlough scheme", The Times, 27 May. Available online at: www.thetimes.co.uk/article/the-dangers-of-becomingaddicted-to-rishi-sunak-s-job-furlough-scheme-7mtlwfdq7 (accessed 10 August).

Thatcher, M. (1990) “Thatcher's Speech to the Czech Federal Assembly”, Making the History of 1989. Available online at: http://chnm.gmu.edu/1989/items/show/74) (accessed 12 August 2020)

Tombs, S. (2016) Social Protection After the Crisis: Regulation Without Enforcement. Bristol: Policy Press. 
Tombs, S., and Whyte, D. (2003) Unmasking the Crimes of the Powerful: Scrutinizing States and Corporations. New York: Peter Lang.

Tombs, S., Whyte, D. (2007) Safety Crimes Cullompton: Willan Publishing.

Tyler, I. (2013) Revolting Subjects: Social Abjection and Resistance in Neoliberal Britain. London: Zed Books.

White, C. and Nafilyan, V., (2020) "Coronavirus-related deaths by ethnic group, England and Wales methodology", Office for National Statistics, 7 May. Available online at: www.ons.gov.uk/peo plepopulationandcommunity/birthsdeathsandmarriages/deaths/methodologies/coronavirusrelated deathsbyethnicgroupenglandandwalesmethodology (accessed 10 August 2020).

Wild, M. (2007) “'On your bike ...”, $B B C, 16$ May. Available online at: http://news.bbc.co.uk/1/hi/ programmes/politics_show/6660723.stm (accessed 10 August 2020).

Wohland, P., Rees, P., Nazroo, J., and Jagger, C. (2015) "Inequalities in healthy life expectancy between ethnic groups in England and Wales in 2001", Ethnicity and Health, 20(4): 341-353. 